\title{
The Development of Learning Material Using Learning Cycle 7E with Socio-scientific Issues Context in Rate of Reaction to Improve Student's Argumentation Skills in Senior High School
}

\author{
Siti Nurlatifah, Tukiran \\ Department of Science \\ Universitas Negeri Surabaya \\ Surabaya, Indonesia \\ sitinurlatifah@mhs.unesa.ac.id
}

\author{
Erman \\ Department of Chemistry \\ Universitas Negeri Surabaya \\ Surabaya, Indonesia
}

\begin{abstract}
The Learning Cycle 7E (LC-7E) with Socioscientific Issue (SSI) Context learning material is learning material that links chemistry learning with science issues and involves moral and ethical component. It will lead students to explore and develop their knowledge by connecting of issues or events in daily life. The aims of this study was to described the effectiveness of learning material using LC-7E with SSI context for improving student's argumentation skill in rate of reaction. The study design used 4-D models and one group pretest-posttest design. The subject was the learning material which the data were collected from 36 students of Science class at $11^{\text {th }}$ Grade. Some results: (1) The learning materials were valid; (2) There was improvement students' argumentation skill, it was shown by the result of pre-test: $1^{\text {stlevel }}=1.4 \% ; 2^{\text {nd }}$ level $=69.4 \% ; 3^{\text {rd }}$ level $=29.2 \%$; level $4^{\text {th }}$ level $=0 \%$ and the result of post-test: $1^{\text {st }}$ level $=0 \% ; 2^{\text {nd }}$ level $=14.6 \% ; 3^{\text {rd }}$ level $=52.1 \%$; level $4^{\text {th }}=33.3 \% ;(3)$ The was improvement students' mastery concepts, it was shown by the result of pre-test all the students' were not pass and the result of post-test the students' mastery concept completeness was $94,4 \%$. The conclusion of this study, the learning material is appropriate to improve students' argumentation skill in rate of reaction.
\end{abstract}

\section{INTRODUCTION}

The development in the $21^{\text {st }}$ century has entered various joints of life, including the field of education. Teachers and students, educators and learners are required to have appropriate teaching and learning skills in this $21^{\text {st }}$ century. As an effort to prepare human resources which of course can survive and also compete in the midst of revolutionary change in $21^{\text {st }}$ century, is needed to develop life skills as well as soft skills, so it can attain a science literacy society that has an understanding of scientific ideas, intellectual ability, creativity, reasoning, and concern for issues and problems that occurs [1].

Basically, the Indonesian government has done a lot of things to improve the quality of human resources. Nevertheless, there is still needed for more effort to achieve the desired goals. It can be seen from the results of science literacy measurements conducted by the OECD from 2003 to 2015 and TIMSS which shown that Indonesia was still in the bottom [2-9].

The low test results are pointed out because the science learning process in schools still emphasized science as a product of knowledge, not emphasized the science as a process of scientific discovery by the scientists which requires students to memorize and to do a complex calculations instead of referring to the context that requires students to improve science literacy [10].

The development of science literacy have same direction with the development of life skills, so to make students to be more independent and have a good science literacy could be developed through the development of student skills related to their life skills and certainly necessary in this $21^{\text {st }}$ century [11]. One of these skills is argumentation skills. This is because, as part of a global society, students are not only required to understand the concepts of science, but also to be active in class discussion [12]. Argumentation is an inseparable part of science. Arguments in science involve reasoning through inference processes based on available data and involve critical thinking skills in making fact-finding statements [13]. Thus, in the practice of learning in the class of argumentation skills is one of important part in terms of students' mastery concept.

Nowadays, students' understanding of the relevance of chemistry in their daily life is the biggest problem. Students regard chemistry as unimportant subject to learn because it is useless for their life [14]. Thus, it will cause the students' argumentation skills having no complexity or low [15]. Not only that, the facts show that many teachers have not yet applied learning which can develop students' argumentation skills. The fact has shown having a same condition with the result of observation and interview in Rengel Senior High School. Where the students only accustomed to memorize a concept without being directed on how to apply their knowledge through a discussion process that can train their scientific reasoning through inference process based on available data and make statements based on the fact that exist. But it does not mean the teachers can't do it. One of the causes is the learning material that can lead students to explore the knowledge of science that is owned by their daily life and as to lead the students to be able to argue during the learning is less.

Based on the problems above, it's needed to develop learning material that can improve students' argumentation skills. It can be done by developing a learning device that links 
the chemistry learning with science-related issues and involves a moral and ethical component called Socio-Scientific (SSI) Issues context [16]. This is because, through this context will encourage students to argue based on conflicts and on social issues science, so it will be easier for students to collect data based on certain facts because it is familiar for them. One of the subjects in chemistry that closely related to the controversial issue in daily life is rate of reaction as: (1) Motor Vehicle Destruction in Coastal Area; (2) Ocean Acidification; (3) Utilization of Bio Detergent in the Future.

The alternative learning model that can be used to improve students' argumentation skills is Learning Cycle 7E model. This model requires group discussion activities, so that through the emphasizing of the phases of this model will make an interaction between students in group to be more structured and the knowledge which is obtained will be a complete knowledge and will provide satisfactory results to improve concept mastery [17].

The result of this study are expected to be empirical evidence in the disseminate process of the LC-7E with SSI context learning material effectiveness to improve the students' argumentation skills in rate of reaction.

\section{EXPERIMENTAL METHOD}

\section{A. Learning Materials' Development Procedure}

This study was performed to know the effectiveness LC 7E with SSI context learning material. This research was done in three stages, i.e. (1) developing the learning material; (2) doing validation and revision the learning material; (3) trying out the learning material in the classroom.

The first stage, the learning material developed used 4D model and one group pretest-posttest design [18]. The stages of 4D model are: (1) Define; (2) Design; (3) Develop; and (4) Disseminate [19].

\section{(1) Define}

The aims of this stage are to set and to define the requirements of the learning. The steps in this stage includes: 1) background analysis; 2) students analysis; 3) task analysis; 4) concept analysis; and 5) developing the learning objectives.

\section{(2) Design}

The steps in this stages includes: 1) selection of learning material to be developed; 2) preparation of tests; 3) selection of formats; and 4) make an initial design

\section{(3) Develop}

The purpose of this stage is to produce LC-7E with SSI context learning material which is have been revised by an expert's. The development of this material is initiated by preparing syllabus, lesson plan, students' book, and students' worksheet and then followed by preparation of students' argumentation skills test and student's mastery concept test.

(4) Disseminate

The process of dissemination is a final stage of this learning material development. This stage is done by disseminating the learning materials resulted.
At the second stage, the LC-7E with SSI context was validated by an expert's judgments by using a validation sheet. After the expert's state the learning material to be valid, then it will be implemented in the classroom to confirm it effectiveness.

At the last stage, the learning material then trying out in the classroom then followed by collecting data to determine the effectiveness of the learning material on improving the students' mastery concepts and students' argumentation skills

\section{B. Participants and Data Collection Tools}

The data was attained from Science class consist of 36 students at $11^{\text {th }}$ grade at Rengel Senior High School Year 20172018. Data collection techniques in this study are validation and test. Validation is used to determine validity the learning material. Test is used to determine the effect of the learning material on improving the students' mastery concepts and students' argumentation skills. In the test conducted pretest and posttest in accordance with learning objectives and indicators listed in the Lesson Plans.

\section{Data Analysis}

In this study, data analysis technique used include: (1) analysis the result of validation of the LC-7E with SSI context learning material; (2) analysis of students' argumentation skills; (3) analysis of students' mastery concept.

(1) Analysis the Result of Validation of the LC-7E with SSI Context Learning Material

The validity of learning material analyzed by using categorizes technique: $4=$ very well; 3 : well; $2=$ less; $1=$ =ery less [20]. The results value of the three validators is then calculated the average then converted by criteria shown in Table 1 [20].

Table 1. Validation Assessment Category

\begin{tabular}{|l|l|}
\hline Scores Range & Category \\
\hline $3,5 \leq \mathrm{P} \leq 4,0$ & Strong Valid \\
\hline $2,9 \leq \mathrm{P} \leq 3,4$ & Valid \\
\hline $2,3 \leq \mathrm{P} \leq 2,8$ & Enough \\
\hline $1,7 \leq \mathrm{P} \leq 2,2$ & Less \\
\hline $1 \leq \mathrm{P} \leq 1,6$ & Invalid \\
\hline
\end{tabular}

Based on the category as mention in Table 1, the learning material developed called to be valid if all of components of the instruments including of LC-7E with SSI context learning material get score $\geq 2.9$.

(2) Analysis the Result of Students' Argumentation Skills

The improvement of students' argumentation skills analyzed by categorize the result of pretest and posttest of students' argumentation, and then converted by category based on the Table 2 and calculation by percentage technique [21].

TABLE 2. STUDENTS' ARGUMENTATION SKILL CATEGORY

\begin{tabular}{|l|l|}
\hline Category & Description \\
\hline $1^{\text {st }}$ Level & The Argument contain a claim \\
\hline $2^{\text {nd }}$ Level & $\begin{array}{l}\text { The Argument contains claim, data, and/or warrant } \\
\text { a. The Argument contains claim and data } \\
\text { b. The Argument contains claim and warrant } \\
\text { c. The Argument contains claim, data, and warrant }\end{array}$ \\
\hline
\end{tabular}


TABLE II. CONT.

\begin{tabular}{|l|l|}
\hline Category & Description \\
\hline $3^{\text {th }}$ Level & $\begin{array}{l}\text { The Argument contains claim, data/warrant, backing or } \\
\text { qualifier } \\
\text { a. The Argument contains claim, data, and backing } \\
\text { b. The Argument contains claim, warrant, and backing } \\
\text { c. The Argument contains claim, data, and qualifier } \\
\text { d. The Argument contains claim, data, warrant, and } \\
\text { backing } \\
\text { e. The Argument contains claim, data, warrant, and } \\
\text { qualifier }\end{array}$ \\
\hline $4^{\text {th }}$ Level & $\begin{array}{l}\text { The Argument contains claim, data/warrant, backing and } \\
\text { qualifier } \\
\text { a. The Argument contains claim, data, backing, and } \\
\text { qualifier } \\
\text { b. The Argument contains claim, warrant, backing and } \\
\text { qualifier } \\
\text { c. The Argument contains claim, data, warrant, backing } \\
\text { and qualifier }\end{array}$ \\
\hline
\end{tabular}

Students' are said to possess the mastery of argumentation skills competence and the LC-7E with SSI context learning material said effectiveness if $\geq 75 \%$ the students' argumentation lied on a minimal category of level 3 .

\section{(3) Analysis the Result of Students' Mastery Concept}

The result of students' mastery concept was attained by analysis the result of pretest and posttest students' mastery concept. The students' are said to pass the test if they was reach minimum value 75 with $\mathrm{C}$ category. The improvement of students' mastery concept was analyzed by using the n-gain equation. The result of n-gain calculation was converted by criteria: High > 0.70; Medium 0.3 - 0.70; Low <0.30 [22].

\section{RESULT AND DISCUSSION}

\section{A. Result}

The result of developed learning material of LC-7E with SSI context were obtained can be reported as follows.

\section{(1) The Validity of Developed LC-7E with SSI Context Learning Material}

The validity of developed LC-7E with SSI context learning material was assessed by experts' judgments (three persons). According of the result, all the learning materials developed are valid. The minimum scores for syllabus is 3.33 and the maximum score is 4.00 ; for lesson plan the minimum score is 3.00 and the maximum score is 4.00 ; for students' worksheet the minimum score is 3.00 and the maximum score is 3.67 ; for students' book the minimum score is 3.00 and the maximum score is 4.00; for students' argumentation test the minimum score is 3.00 and the maximum score is 4.00; and for students' mastery concept test the minimum score is 3.33 and the maximum score is 4.00 . Based on the validation results, the learning material are valid and suitable to use in the learning process in the subject rate of reaction to improve students' argumentation skills because all of components of the instruments including of LC-7E with SSI context learning material get score $\geq 2.9$.

\section{(2) Students' Argumentation Skills}

Students' argumentation skill data is obtained from students' written answers or arguments on issues of science related to reaction rate material. The students' answers are then classified into argument levels to determine the complexity of argumentation that refers to the Toulmin's Argument pattern (TAP) which can be determined from the pre-test and post-test results. The result of pre-test and post-test of students' argumentation skills are presented in Table 3.

Table 3. Students' Argumentation Skills

\begin{tabular}{|c|c|c|c|c|c|c|c|c|c|c|c|c|c|}
\hline \multicolumn{14}{|c|}{ Pre-test } \\
\hline \multirow{2}{*}{ NQ } & \multirow{2}{*}{$1^{\text {st }}$ Level } & \multicolumn{3}{|c|}{$2^{\mathrm{nd}}$ Level } & \multicolumn{6}{|c|}{$3^{\text {rd }}$ Level } & \multicolumn{3}{|c|}{$4^{\text {th }}$ Level } \\
\hline & & $2 a$ & $2 \mathrm{~b}$ & $2 \mathrm{c}$ & $3 \mathbf{a}$ & $3 \mathrm{~b}$ & $3 c$ & $3 d$ & $3 e$ & 3f & $4 a$ & $4 \mathrm{~b}$ & $4 \mathrm{c}$ \\
\hline 1 & 0 & 5 & 4 & 15 & 0 & 0 & 2 & 0 & 8 & 2 & 0 & 0 & 0 \\
\hline 2 & 0 & 9 & 6 & 10 & 0 & 1 & 2 & 0 & 7 & 1 & 0 & 0 & 0 \\
\hline 3 & 1 & 12 & 0 & 10 & 2 & 3 & 1 & 0 & 7 & 0 & 0 & 0 & 0 \\
\hline 4 & 1 & 7 & 1 & 21 & 1 & 1 & 0 & 0 & 3 & 1 & 0 & 0 & 0 \\
\hline$\sum A$ & 2 & \multicolumn{3}{|c|}{100} & \multicolumn{6}{|c|}{42} & \multicolumn{3}{|c|}{0} \\
\hline$\%$ & 1.4 & \multicolumn{3}{|c|}{69.4} & \multicolumn{6}{|c|}{29.2} & \multicolumn{3}{|c|}{0} \\
\hline \multicolumn{14}{|c|}{ Post-test } \\
\hline \multirow{2}{*}{ NQ } & \multirow{2}{*}{$1^{\text {st }}$ Level } & \multicolumn{3}{|c|}{$2^{n^{\mathrm{d}}}$ Level } & \multicolumn{6}{|c|}{$3^{\text {rd }}$ Level } & \multicolumn{3}{|c|}{$4^{\text {th }}$ Level } \\
\hline & & $2 a$ & $2 \mathrm{~b}$ & $2 \mathrm{c}$ & $3 \mathbf{a}$ & $3 \mathrm{~b}$ & $3 \mathrm{c}$ & $3 d$ & $3 e$ & $3 \mathrm{f}$ & $4 a$ & 4b & $4 \mathrm{c}$ \\
\hline 1 & 0 & 2 & 1 & 0 & 2 & 2 & 0 & 0 & 21 & 0 & 0 & 0 & 8 \\
\hline 2 & 0 & 1 & 3 & 2 & 0 & 0 & 2 & 0 & 12 & 7 & 1 & 0 & 8 \\
\hline 3 & 0 & 2 & 0 & 1 & 0 & 0 & 3 & 0 & 5 & 1 & 0 & 0 & 24 \\
\hline 4 & 0 & 1 & 3 & 5 & 1 & 0 & 0 & 0 & 18 & 1 & 0 & 0 & 7 \\
\hline$\sum A$ & 0 & \multicolumn{3}{|c|}{21} & \multicolumn{6}{|c|}{75} & \multicolumn{3}{|c|}{48} \\
\hline$\%$ & 0 & \multicolumn{3}{|c|}{14.6} & \multicolumn{6}{|c|}{52.1} & \multicolumn{3}{|c|}{33.3} \\
\hline
\end{tabular}
argument)

Based on Table 3, the result of students' argumentation skills when pre-test was still low. $1^{\text {st }}$ level as much as $1.4 \%$ and $2^{\text {nd }}$ level with the highest total argument $14.6 \%$. However, it does not mean that no student has been able to make arguments with high complexity. This is indicated by the existing students who reached $3^{\text {rd }}$ level as much as $29.2 \%$ although there was no student in $4^{\text {th }}$ level. Meanwhile, after the implementation Learning Cycle 7E model with SSI context, students' argumentation skill has improved. The data result of students' argumentation skills improvement is supported by the result of the students' mastery concept.

The improvement students' argumentation skills through LC-7E with SSI context learning material are presented in Figure 1:

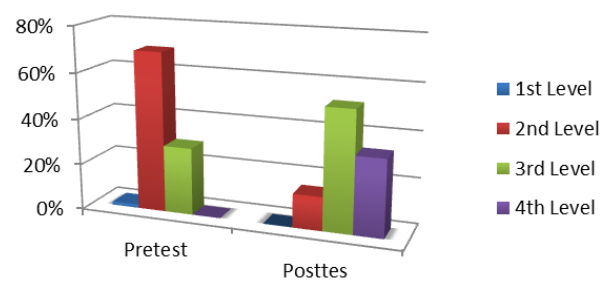

Figure 1. The Improvement Students' Argumentation Skills

The overall result based Figure 1, students' argumentation skills has improved. It was shown by $\geq 75 \%$ of students' argument was reach $3^{\text {rd }}$ level and $4^{\text {th }}$ level.

(3) Mastery Concept Test

Result of students' mastery concept shown in the Table 4. 
TABLE IV. STUDENTS' MASTERY CONCEPT

\begin{tabular}{|c|c|c|c|c|c|c|c|c|}
\hline \multirow[b]{2}{*}{$\begin{array}{l}\text { St } \\
\text { ud } \\
\text { en } \\
\text { ts }\end{array}$} & \multicolumn{3}{|c|}{ Pre-test } & \multicolumn{3}{|c|}{ Post-test } & \multirow[t]{2}{*}{ n-Gain } & \multirow[t]{2}{*}{ Category } \\
\hline & $\begin{array}{l}\text { Sc } \\
\text { ore }\end{array}$ & $\begin{array}{l}\text { Descr } \\
\text { iption }\end{array}$ & $\begin{array}{l}\mathrm{Ca} \\
\text { te } \\
\text { go } \\
\text { ry }\end{array}$ & $\begin{array}{l}\text { Sc } \\
\text { ore }\end{array}$ & $\begin{array}{l}\text { Descrip } \\
\text { tion }\end{array}$ & $\begin{array}{l}\text { Cate } \\
\text { gory }\end{array}$ & & \\
\hline 1 & 20 & Failed & $\mathrm{D}$ & 93 & Passed & $\bar{A}$ & 0.91 & Very High \\
\hline 2 & 50 & Failed & $\mathrm{D}$ & 97 & Passed & $\bar{A}$ & 0.94 & Very High \\
\hline 3 & 23 & Failed & $\mathrm{D}$ & 90 & Passed & $\mathrm{B}$ & 0.87 & Very High \\
\hline 4 & 40 & Failed & $\mathrm{D}$ & 93 & Passed & A & 0.88 & Very High \\
\hline 5 & 20 & Failed & $\mathrm{D}$ & 80 & Passed & $\mathrm{B}$ & 0.75 & High \\
\hline 6 & 33 & Failed & $\mathrm{D}$ & 90 & Passed & B & 0.85 & Very High \\
\hline 7 & 50 & Failed & $\mathrm{D}$ & $\begin{array}{c}10 \\
0\end{array}$ & Passed & A & 1.00 & Very High \\
\hline 8 & 50 & Failed & $\mathrm{D}$ & 90 & Passed & $\mathrm{B}$ & 0.80 & High \\
\hline 9 & 53 & Failed & $\mathrm{D}$ & 93 & Passed & $\bar{A}$ & 0.85 & Very High \\
\hline 10 & 20 & Failed & $\mathrm{D}$ & 93 & Passed & $\mathrm{A}$ & 0.91 & Very High \\
\hline 11 & 40 & Failed & $\mathrm{D}$ & 93 & Passed & $\mathrm{A}$ & 0.88 & Very High \\
\hline 12 & 50 & Failed & $\mathrm{D}$ & 97 & Passed & $\bar{A}$ & 0.94 & Very High \\
\hline 13 & 50 & Failed & $\mathrm{D}$ & 90 & Passed & $\mathrm{B}$ & 0.80 & Very High \\
\hline 14 & 43 & Failed & $\mathrm{D}$ & 93 & Passed & $\bar{A}$ & 0.88 & Very High \\
\hline 15 & 40 & Failed & $\mathrm{D}$ & 57 & Failed & $\mathrm{D}$ & 0.28 & Low \\
\hline 16 & 30 & Failed & $\mathrm{D}$ & 77 & Passed & $\bar{C}$ & 0.67 & High \\
\hline 17 & 17 & Failed & $\mathrm{D}$ & 67 & Failed & $\mathrm{D}$ & 0.60 & Midle \\
\hline 18 & 50 & Failed & $\mathrm{D}$ & 97 & Passed & $\mathrm{A}$ & 0.94 & Very High \\
\hline 19 & 43 & Failed & $\mathrm{D}$ & 90 & Failed & $\mathrm{B}$ & 0.82 & Very High \\
\hline 20 & 50 & Failed & $\mathrm{D}$ & 97 & Passed & $\mathrm{A}$ & 0.94 & Very High \\
\hline 21 & 50 & Failed & $\mathrm{D}$ & $\begin{array}{c}10 \\
0\end{array}$ & Passed & A & 1.00 & Very High \\
\hline 22 & 53 & Failed & $\mathrm{D}$ & 93 & Passed & A & 0.85 & Very High \\
\hline 23 & 57 & Failed & $\mathrm{D}$ & 93 & Passed & $\mathrm{A}$ & 0.84 & Very High \\
\hline 24 & 20 & Failed & $\mathrm{D}$ & 80 & Passed & B & 0.75 & High \\
\hline 25 & 50 & Failed & $\mathrm{D}$ & 97 & Failed & A & 0.94 & Very High \\
\hline 26 & 60 & Failed & $\mathrm{D}$ & 93 & Failed & A & 0.83 & Very High \\
\hline 27 & 57 & Failed & $\mathrm{D}$ & 93 & Passed & $\mathrm{A}$ & 0.84 & Very High \\
\hline 28 & 23 & Failed & $\mathrm{D}$ & 97 & Failed & $\overline{\mathrm{A}}$ & 0.96 & Very High \\
\hline 29 & 33 & Failed & D & 90 & Passed & B & 0.85 & Very High \\
\hline 30 & 27 & Failed & $\mathrm{D}$ & 97 & Passed & A & 0.96 & Very High \\
\hline 31 & 50 & Failed & $\mathrm{D}$ & 97 & Passed & A & 0.94 & Very High \\
\hline 32 & 33 & Failed & D & 93 & Passed & A & 0.90 & Very High \\
\hline 33 & 37 & Failed & $\mathrm{D}$ & 97 & Passed & A & 0.95 & Very High \\
\hline 34 & 43 & Failed & D & 97 & Passed & A & 0.95 & Very High \\
\hline 35 & 40 & Failed & $\mathrm{D}$ & 90 & Passed & B & 0.83 & Very High \\
\hline \multirow[t]{2}{*}{36} & 43 & Failed & $\mathrm{D}$ & 97 & Passed & A & 0.95 & Very High \\
\hline & \multicolumn{3}{|c|}{$\begin{array}{l}\text { Failed } \\
\text { Passed }\end{array}$} & \multicolumn{3}{|c|}{$\begin{array}{ll}\text { Failed } & : 94.4 \% \\
\text { Passed } & : 5.6 \%\end{array}$} & & \\
\hline
\end{tabular}

Note: Category $(\mathrm{A}=91-100 ; \mathrm{B}=80-90 ; \mathrm{C}=70-79 ; \mathrm{D}=<70)$

Based on the Table 4, at the time of pre-test, all students did not pass the test but at the time of post-test 34 students passed the test. Student completeness in learning was reach $94.4 \%$. The average of n-gain score is 0.86 which is very high $n$-gain category is dominate. It can be concluded that Learning Cycle 7E model with SSI context learning material can improve students' mastery concept. All the data results are also supported by the validation result which was shown that all the learning material developed were valid and suitable to be implemented.

\section{B. Discussion}

As mention above, the purposes of this study were to develop leaning material using LC-7E with SSI context and to describe the validity and the effectiveness of the learning material to improve students' argumentation skills.
Many researches which were had same purpose with this study was did. However, research that related to development of learning material using LC-7E with SSI context to improve students' argumentation skills had not been studied yet, such as research conducted by: (1) Khisfe (2013); and (2) Shoulders (2012) reported that with SSI context learning the students' argumentation skills increase [23-24].

Firstly, the LC-7E with SSI context learning material had been stated to be strong theoretically by expert's appraisal. It was supported by the scores given by the expert's with the minimum score 3.00 and the maximum score 4.00 while the criteria were valid and strong valid. Thus, the learning material was ready to be implemented in the classroom.

Secondly, the effectiveness of the learning material can be confirmed by two data results: (1) data related students' argumentation skill; (2) data related students' mastery concept. Based on these results, there were improvement of students' argumentation skills and students' mastery concept. Thus, it can be seen that the LC-7E with SSI contexts learning material is effective for improving students' argumentation skills.

Learning Cycle 7E with SSI context effective to improve students' argumentation skills because the phases of this model: (1) Elicit; (2) Engage; (3) Explore; (4) Explain; (5) Elaborate; (6) Evaluate; (7) Extend, are able to express student ideas, explain how an event happened, conduct an analysis, collect facts and solve other problems by using concepts their understood [25]. While SSI is chosen as a learning context because SSI can be used to: (1) make science learning more relevant with students' daily life; (2) directing learning outcomes, such as understanding the nature of science; (3) enhancing argument dialogue; (4) improving the ability to evaluate scientific information; and (5) developing science literacy [26]. The learning with SSI context has the following components: 1) Scientific Background; 2) Evaluation of Information; 3) Assessing local, national, and global dimension impacts; 4) Decision Making [1]. Thus, all the SSI components are entered in the LC-7E phases.

In the Elicit phase, students will be directed to communicate arguments to explore the initial knowledge. The second phase is Engage. In this phase the teachers will presents science issues (Scientific Background). The students will be train to communicate arguments to response the SSI issues presented. The next phase is Explore, in this phase the students will evaluate the science issues presented (Evaluation of Information), so that the students will communicate their arguments based on the results of discussions, experiments, and evaluation of science issues. The next phase is explain, the students will communicate the argument based on the results of discussions and experiments. The fifth phase is Elaborate, the students will be trained to write the argument by transferring the knowledge they have then communicate it. The sixth phase is Evaluate. In this phase the student will be directed to write down their argument to solve the problem. Thus, the teachers can check the students' understanding of the material that has been studied. The last phase is Extend. All of the components of SSI are entered in this phase i.e. 1) scientific Background; 2) evaluation of information; 3) Assessing local, national, and global dimension impacts; and 4) Decision Making. Thus, the students will be able to communicate and debrief arguments by linking concepts their obtained with SSI issues. 
Based on the above description can be concluded that the existence of SSI context entered in the phases of Learning Cycle 7E will make students' thinking patterns become systematic and structured, and also will make students easy to understand and to remember the lesson through their knowledge because of the learning is closely related to their daily life.

The result of improving students' argumentation skills is also supported by the result of the improvement of students' mastery concept. This is because the learning phases in this learning model are suitable with the students' cognitive development that is formal operational stage, a stage where students can already think abstractly / symbolically and solve the problem through experiment [27].

In the Elicit phase, the teacher should try to bring up the prior knowledge of students related to the material by giving learners some questions related to the concepts of the material with a phenomenon that exists in their daily life [28]. The engagement stage is an early stage in which students are given apperception and motivation with phenomena that are close to daily life and the teacher try to attract the interest and readiness of the students to follow the learning [29]. The next phase is the stage of explore. This phase is an important phase because at this stage students begin to enter into the subject matter. This phase provides an opportunity for students interacting with the environment through activities such as practicum, analyse solutions, discussing natural phenomena, observing natural phenomena or social behaviour [29]. The next phase is Explain, where this phase will provide an opportunity for students to complete, refine and develop their concepts by explaining the concepts with their own sentences. In this phase students find the terms of the concepts studied [30]. The next phase is Elaborate, where in this phase students will be required to take advantage of the concepts that have been obtained to solve other problems [31]. In the next phase that is evaluate phase, the teacher will give the student an opportunity for implementing their concept to solve problem exercises and also to evaluate all the phase passed [30-32]. The last phase in the Learning Cycle 7E model is extend, that will make the students to apply the concepts or knowledge in the new context. So that, students were expected to be able to build a new knowledge in their own minds by implementing previously acquired knowledge to solve existing problems [33].

\section{CONCLUSION}

The LC-7E with SSI context learning material was valid according to the result of the validation by the experts'. The effectiveness of the learning material can be considered by two aspects, i.e. students' argumentation skills and students' mastery concept. The research reported that the students' argumentation skills and the students' mastery of concepts showed significantly improvement during learning process. Referring to the aims of this study and supported by the result and discussion, it can be concluded that the LC-7E with SSI context learning material is effective to improve students' argumentation skills in rate of reaction.

\section{ACKNOWLEDGMENT}

The authors would like to thank to Rengel Senior High School that has facilitated this research.

\section{REFERENCES}

[1] Pratiwi, Yunilia Nur 2016 The Socioscientific Issues (SSI) in reaction rates topic and its effect on the critical thinking skills and argumentation skills of high school students (Malang: Malang University)

[2] OECD 2003 Literacy Skills for the World of Tomorrow-Further Result from PISA 2003 (Paris: OECD Publishing)

[3] OECD 2006 Assesing Scientific, reading, and Mathematical Literacy: A Framework for PISA 2006 (Paris: OECD Publishing)

[4] OECD 2009 The PISA 2009 Assesment Framework: Mathematics, reading science and problem solving knowledge and skills (Paris: OECD Publishing)

[5] OECD 2012 PISA 2009 Technical Report PISA (Paris: OECD Publishing)

[6] OECD 2013a Assesment and Analitycal Framework Mathematics, reading, Science, Problem Solving and Financial Literacy.For PISA 2012 s.l (Paris: OECD Publishing)

[7] OECD 2013b PISA 2012 Result: What Student Know and Can DoStudent Performance in Mathematics, Reading, Science (Paris: OECD Publishing)

[8] OECD 2015 Education at a Glance 2015: OECD Indicators (Paris: OECD Publishing)

[9] Balitbang 2011 Survei Internasional TIMSS (Trends In International Mathematics and Science Study) http://litbang.kemdikbud.go.id/- detail.php?id=214)

[10] Hurd P D 1997 J. Science Education 82 p.407

[11] Rychen, D.S. \& Salganik, L.H. 2003 Key Competencies for a Successful Life and $a$ Well Functioning Society (Cambridge, MA: Hogrefe \& Huber)

[12] Kuhn D and W Udell 2003 The Development of Argument Skills http://mx1.educationforthinking.org)

[13] Pallant A and Lee H S 2014 J. of Science Educational Technology 24 p. 378

[14] Alkenhead G S 2003 Research and Practice 4 p.115

[15] Khisfe R 2013 International Journal of Science Education 36 p.974

[16] Sadler T D 2004 J. Science Educator 13 p.4

[17] Hanuscin D L and Lee M H 2008 J. of Elementary Science Education 20 p.51

[18] Creswell J 2007 Qualitative Inquiry \& Research Design: Choosing Among Five Approaches, 2nd ed (California: Sage Publication)

[19] Thiagarajan S Smmel and D S Smmel M I 1974 Instruksional Development for teacher of exceptional Children (Blomington: Indiana University)

[20] Riduwan M B A 2010 Measurement scale of research variables (Bandung: Alfabeta)

[21] Cetin P S 2014 Research in Science and Technological Education 321

[22] Hake Richard R 1999 Analyzing Change/Gain Score. American Educational Research Metodhology http://lists.asu.edu/cgi-bin/wa?A2=ind9903\&L=aera-d\&P=R6855

[23] Khisfe Rola 2013 International Journal of Science Education 36974

[24] Shoulders C W 2012 The Effects of A Socioscientific Issues Instructional Model in Secondary Agricultural Education on Students' Content Knowledge, Scientific Reasoning Ability, Argumenation Skills, and Views of The Nature of Science http://ufdcimages.uflib.ufl.edu/UF/E0/04/40/27/00001/SHOULDERS_pdf

[25] Lorsbach W A 2008. The Learning Cycle as a Tool Planning Science Instruction (United States of Amerika: Illionis State University)

[26] Sadler T D and Zeidler D L 2004 J. Science Education 8839

[27] Slavin Robert E 2011 Educational Psycology (Jakarta: PT.Indeks)

[28] Bransford J B A and Cocking R 2000 Learning and Transfer. In How People Learn: Brain, Mind, Experience, and School (Expanded Edition) (Washington,D.C: National Academy Press) pp.51-78

[29] Balta N and Sarac H 2016 J. European Educational Research 561

[30] Eisenkraft Arthur 2003 International J. Science Education 281463 
[31] Huang K J Liu, T C Graf S, and Lin Y C Embedding mobile technology to Outdoor Natural science Learning Based on the 7E Learning Cycle 2008 (China : National Central University Taiwan)
[32] Colburn A and Clough M P 1997 J. The Science Teacher 6430

[33] Erlina Nia 2016 J. Penelit. Pend. Sains. 52 